\title{
Urgences
}

\section{Une enseigne...}

\section{Céline Bouchard}

Numéro 13, mars 1986

\section{Éclats d'atelier}

URI : https://id.erudit.org/iderudit/025196ar

DOI : https://doi.org/10.7202/025196ar

Aller au sommaire du numéro

\section{Éditeur(s)}

Urgences

\section{ISSN}

0226-9554 (imprimé)

1927-3924 (numérique)

Découvrir la revue

\section{Citer ce document}

Bouchard, C. (1986). Une enseigne... Urgences, (13), 11-11.

https://doi.org/10.7202/025196ar d'utilisation que vous pouvez consulter en ligne.

https://apropos.erudit.org/fr/usagers/politique-dutilisation/ 


\section{Céline Bouchard}

Une enseigne lumineuse retient le signe d'un lieu illusoire. Une porte ornée de trois vitres d'or ouvre le mur qui dissimule un tumulte de gens givrés d'hiver. Dix lignes pointillées se suivent vers un même intérieur et selon le même éloignement d'esprit. Tous s'élèvent vers le seuil d'une deuxième porte moins souillée. Le week-end, tous viennent quêter le rêve sur un fond de toile.

Les voyeurs ignorent l'identité de leurs voisins. Les sièges sont dissipés hors du temps. Les gens fixent le voile qui s'ouvre lentement. Tous siègent pour résoudre l'énigme d'une histoire de kimono rouge. Des jours et des nuits sont projetés sous leurs yeux de mortels intimidés, qui font surgir une impression puérile de leurs sens.

Un homme, une femme et un minou sont les sujets visés. Le minou frôle une porte vieille de mille et un jours, qui se détériore visuellement entre le rouge et le noir. Les témoins reposent leurs visions sur l'irréel présent et sur l'iris mensonger des sujets. Le feu les invite sur le seuil d'une mort insensée. Depuis plus de trois heures, les joueurs soufflent des mots et poussent des gestes pour rompre le rythme du temps perdu.

Il est zéro heure. Les solitudes jouissent pleinement. II ne reste plus qu'une empreinte irréelle que l'on réinvente pour voir filer le temps. Tous relèvent leurs vêtements déposés sur les sièges. Tous s'orientent vers une porte enneigée pour sortir... Tout se déroule sur le quotidien trottoir des mémoires. 